\title{
Incorporation of an invasive plant into a native insect herbivore food web
}

Menno Schilthuizen, Lúcia P Santos Pimenta, Youri Lammers, Peter J Steenbergen, Marco Flohil, Nils G.P. Beveridge, Pieter T van Duijn, Marjolein M Meulblok, Nils Sosef, Robin van de Ven, Ralf Werring, Kevin K Beentjes, Kim Meijer, Rutger A Vos, Klaas Vrieling, Barbara Gravendeel, Young Choi, Robert Verpoorte, Chris Smit, Leo W Beukeboom

The integration of invasive species into native food webs represent multifarious dynamics of ecological and evolutionary processes. We document incorporation of Prunus serotina (black cherry) into native insect food webs. We find that $P$. serotina harbours a herbivore community less dense but more diverse than its native relative, $P$. padus (bird cherry), with similar proportions of specialists and generalists. While herbivory on $P$. padus remained stable over the past century, that on $P$. serotina gradually doubled. We show that $P$. serotina may have evolved changes in investment in cyanogenic glycosides compared with its native range. In the leaf beetle Gonioctena quinquepunctata, recently shifted from native Sorbus aucuparia to $P$. serotina, we find divergent host preferences on Sorbus- versus Prunus-derived populations, and weak host-specific differentiation among 380 individuals genotyped for 119 SNP loci. We conclude that evolutionary processes may generate a specialized herbivore community on an invasive plant, allowing prognoses of reduced invasiveness over time. On the basis of the results presented here, we would like to caution that manual control might have the adverse effect of a slowing down of processes of adaptation, and a delay in the decline of the invasive character of $P$. serotina. 
1 [title]

2

4

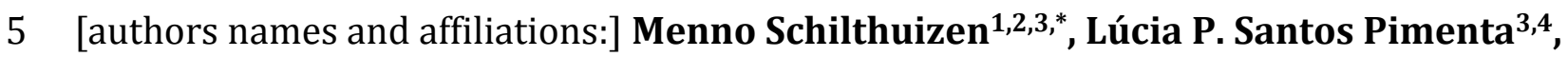

6 Youri Lammers $^{1}$, Peter J. Steenbergen ${ }^{3}$, Marco Flohil ${ }^{5}$, Nils Beveridge ${ }^{1,3}$, Pieter T. van

7 Duijn ${ }^{1,6}$, Marjolein M. Meulblok ${ }^{1,6}$, Nils Sosef ${ }^{1,6}$, Robin van de Ven ${ }^{1,6}$, Ralf Werring ${ }^{1,6}$,

8 Kevin Beentjes ${ }^{1}$, Kim Meijer ${ }^{2}$, Rutger A. Vos ${ }^{1,7}$, Klaas Vrieling ${ }^{3}$, Barbara

9 Gravendeel $^{1,3,6}$, Young Choi ${ }^{3}$, Rob Verpoorte ${ }^{3}$, Chris Smit ${ }^{2}$, Leo W. Beukeboom²
11

12

13

14 serotina

1 Naturalis Biodiversity Center, Leiden, the Netherlands, 2 University of Groningen, Groningen, the Netherlands, 3 Leiden University, Leiden, the Netherlands, 4 Departamento de Química, Instituto de Ciências Exatas, Universidade Federal de Minas Gerais, Belo Horizonte, MG, 31270-901, Brazil, 5 ServiceXS, Leiden, the Netherlands, 6 University of Applied Sciences, Leiden, the Netherlands; 7 University of Amsterdam, Amsterdam, the Netherlands

${ }^{*}$ Corresponding author. Naturalis Biodiversity Center, Darwinweg 2, 2333 CR Leiden, the Netherlands. Tel.: +31-6-22030313. E-mail: menno.schilthuizen@naturalis.nl

[keywords:] Exotic plants; insect herbivores; adaptation; secondary metabolites; Prunus 


\section{Abstract}

23 The integration of invasive species into native food webs represent multifarious dynamics

24 of ecological and evolutionary processes. We document incorporation of Prunus serotina

25 (black cherry) into native insect food webs. We find that $P$. serotina harbours a herbivore

26 community less dense but more diverse than its native relative, P. padus (bird cherry), with

27 similar proportions of specialists and generalists. While herbivory on P. padus remained

28 stable over the past century, that on $P$. serotina gradually doubled. We show that $P$. serotina

29 may have evolved changes in investment in cyanogenic glycosides compared with its native

30 range. In the leaf beetle Gonioctena quinquepunctata, recently shifted from native Sorbus

31 aucuparia to P. serotina, we find divergent host preferences on Sorbus- versus Prunus-

32 derived populations, and weak host-specific differentiation among 380 individuals

33 genotyped for 119 SNP loci. We conclude that evolutionary processes may generate a

34 specialized herbivore community on an invasive plant, allowing prognoses of reduced

35 invasiveness over time. On the basis of the results presented here, we would like to caution

36 that manual control might have the adverse effect of a slowing down of processes of

37 adaptation, and a delay in the decline of the invasive character of P. serotina. 


\section{Introduction}

39 The introduction and subsequent explosive spread of non-native species is seen as one of

40 the main environmental disturbances threatening ecosystems globally (Glowka et al., 1994;

41 Gurevitch \& Padilla, 2004; Simberloff, 2011). Not all introduced species will eventually

42 successfully establish themselves and spread invasively (Williamson \& Fitter, 1996). For

43 example, populations of colonists may die out due to disease or adverse environmental

44 conditions (Rodriguez-Cabal et al., 2013). Nonetheless, the numbers of environmentally

45 problematic exotics are increasing worldwide (Butchart et al., 2010). This even holds for

46 parts of the world that are traditionally seen as sources, rather than recipients of exotic

47 species, such as Europe (Hulme et al., 2009; van Kleunen et al., 2015).

48

49

50

51

52

53

54

55

56

57

58

59

One potential explanation for the invasiveness of an introduced species is the so-called enemy release hypothesis, ERH (Keane \& Crawley, 2002; Liu \& Stiling, 2006), which states that, because the introduced species has not coevolved with the native biota, release from specialized parasites and predators causes explosive population growth.

Enemy release may cause the initial spread, but the subsequent population dynamics are more complex, and influenced by evolutionary processes. Reduced selection pressure for defences against specialist herbivores may result in the evolution of changed energy investment. For example, the plant may evolve stronger allocation of resources towards growth and reproduction and/or towards defence against generalists (Blossey \& Nötzold, 1995; Joshi \& Vrieling, 2005; Zangerl \& Berenbaum, 2005; Prentis et al., 2008; Whitney \& Gabler, 2008). However, at the same time, native herbivores may evolve the ability to locate and feed on introduced species (Vellend et al., 2007; Pearse \& Hipp, 2014). 
60 Therefore, the course of the establishment of an introduced species is complex, with

61 population dynamics modified by evolution: over time, the community of natural enemies

62 attacking an introduced species tends to expand (Brändle et al., 2008) and the adverse

63 impact of invasive species tends to wane (Williamson, 1996; Simberloff \& Gibbons, 2004;

64 Blackburn et al., 2009; Dostál et al., 2013). This may be due to evolution in both the invader

65 and the species it interacts with (Vellend et al., 2007). However, a species' invasive

66 character is often considered static, and management policies rarely consider the

67 possibility that it may change due to evolutionary adaptation (Whitney \& Gabler, 2008).

68 One prominent invasive plant species in Europe is the black cherry, Prunus serotina Ehrh,

69 native of eastern North America and considered a "forest pest" in Europe after widespread

70 planting as auxiliary tree in pine plantations throughout the $20^{\text {th }}$ century (Schütz, 1988;

71 Bakker, 1963; Starfinger et al., 2003). Being bird-dispersed, it has been rapidly invading

72 forested and open habitats (Deckers et al., 2005). In many European countries (Starfinger

73 et al., 2003), it is now considered one of the most important threats to habitat quality of

74 vegetation on dry, acidic, and/or poor soil, such as dunes and moorland (Fig. 1; Godefroid

75 et al., 2005). In the Netherlands, for example, P. serotina has increased in distribution and

76 abundance by at least two orders of magnitude during the second half of the $20^{\text {th }}$ century

77 (Tamis et al., 2005). Current control measures (chemical and mechanical eradication) are

78 temporary and cosmetic (Starfinger et al., 2003). Nonetheless, they are costly: Reinhardt et

79 al. (2003) conservatively calculated the annual cost of P. serotina control in Germany to be

80 ca. 25 million euros.

81 Possibly the initial spread of $P$. serotina was facilitated by an absence of natural enemies; 
82 for example, Reinhart et al. (2003) found that, in the native range, soil pathogens inhibit the

83 establishment of $P$. serotina seedlings near conspecifics, whereas in the invaded range, the

84 species-specific soil community facilitates establishment. However, it is to be expected that

85 the rich resource which P. serotina constitutes will provide adaptive opportunities for

86 phytophagous insects to exploit. Such an evolutionary process will be even more likely if $P$.

87 serotina represents an enemy-free space for herbivores (see Feder [1995] and Karolewski

88 et al. [2014] for examples in other plants), and if it has been evolving reduced herbivore

89 defences (Blossey \& Nötzold, 1995). The changes in chemical defences may be complex.

90 Joshi \& Vrieling (2005) found that invasive plants may increase energetically cheap

91 defences aimed at generalist herbivores, while reducing costly defences aimed at

92 specialists when these specialists are no longer present.

93 Reports of native insects exploiting introduced P. serotina in Europe have been scarce

94 throughout much of the $20^{\text {th }}$ century, and have mostly concerned accidental feeding (by,

95 e.g., moths, aphids, weevils, and leaf beetles; Korringa, 1947; Hille Ris Lambers, 1971;

96 Moraal, 1988; Klaiber, 1999; Fotopoulos, 2000). Simultaneously, at least among nature

97 management workers, a widespread belief has been maintained that the strong cyanogenic

98 properties of the species, stronger than in P. padus (Poulton, 1990; Swain et al., 1991;

99 Santamour, 1998; Hu \& Poulton, 1999; Fitzgerald, 2008; Pimenta et al., 2014), have

100 prevented native insect herbivores from colonizing it (Nyssen et al., 2013; Anonymous,

101 2014). More recently, however, studies from France, Germany, the Netherlands, and Poland

102 are beginning to suggest that a community of native herbivores may in fact be

103 accumulating on P. serotina (Karolewski et al., 2014; Wimmer \& Winkel, 2000; Winkelman,

104 2005; Nowakowska \& Halarewicz, 2006; Żmuda et al., 2008; Boucault, 2009; Halarewicz \& 
105 Jackowski, 2011; Meijer et al., 2012; Karolewski et al., 2013).

106 In this paper, we investigate the composition of the insect herbivore community feeding on

107 P. serotina in the Netherlands. Because congenerics are likely to have been an important

108 source of colonists, we compare the P. serotina herbivore community with the one

109 occurring locally on P. padus, its closest native relative in the Netherlands (Bortiri et al.,

110 2001). To obtain an impression of the accumulation of herbivory in P. serotina, herbivore

111 damage in both Prunus species is quantified on the basis of herbarium records. We then

112 investigate the impact that two conditions may have had on herbivore presence:

113 cyanogenic defence compounds and parasitoid attack, in both Prunus species. Finally, as an

114 example of the adaptive evolution that specialist $P$. serotina herbivores may have

115 undergone, we studied host preference and genomics in one particular P. serotina

116 herbivore, the leaf beetle Gonioctena quinquepunctata. 
118 Materials and Methods

119

120 Sampling herbivore communities on P. serotina and P. padus

121

122 The insect community feeding on both Prunus species was sampled in Nationaal Park Zuid-

123 Kennemerland $\left(52^{\circ} 25^{\prime} \mathrm{N}, 4^{\circ} 35^{\prime} \mathrm{E}\right)$, a partly forested area of coastal sand dunes near

124 Haarlem, the Netherlands. Sampling was done by traversing a $2 \times 2 \mathrm{~km}$ area in the old,

125 forested dunes, and haphazardly selecting 300 individuals ( 150 of each species). We took

126 care that on each day, roughly equal numbers of P. padus and P. serotina were investigated.

127 Where possible, individuals of the two species were sampled in alternation. Sampling was

128 done manually (no tools like nets, beating trays, or exhausters were used) in spring and

129 early summer of 2009 ( 3 days), 2010 (10 days), and 2012 (8 days), by a single person

130 inspecting, for $5 \mathrm{~min}$., leaves, twigs, flowers, and fruits up to c. $2.5 \mathrm{~m}$ above ground level. All

131 insects feeding or ovipositing on the host plant were stored in $96 \%$ ethanol. To obtain

132 measurements on the actual amount of foliage searched, we replicated the above sampling

133 method in September 2015 on 10 and 8 trees, respectively, of P. serotina and P. padus, and

134 counted the numbers of leaves and lengths of twigs searched. We also determined fresh

135 weights of ten leaves of each of the two plant species. Insects were identified

136 morphologically, with help from experts (see Acknowledgements). The 2009 and 2010

137 Geometridae and Tortricidae were identified by sequencing of the Cytochrome Oxidase I

138 DNA-barcode region (e.g., Van Nieukerken et al., 2011) and the "animal identification"

139 module in BOLD (www.boldsystems.org). All 2009 and 2010 specimens were deposited in

140 the collections of Naturalis Biodiversity Center (container codes BE90711-90716). Because 
141 of improper curation, the specimens from the 2012 sampling were discarded after

142 identification. We adopted Leather's (Leather, 1985) host range indicators of G (generalist,

143 feeding on multiple plant families), R (feeding on Rosaceae only), P (on Prunus only), and M

144 (monophagous, feeding on P. padus only). In addition, we categorized species that are

145 specialized on non-Rosaceae (e.g., Quercus-specialists) as 0 ("other"). Differences in species

146 richness for each of these categories were compared between both host species and tested

147 for significance with a chi-square test. Natuurmonumenten (Ruud Luntz) permitted us to

148 work in Nationaal Park Zuid-Kennemerland under permit No. 19 of 2008. Dunea (Harrie

149 van der Hagen) permitted us to work in Meijendel by permission 25/2/2013.

150

151 Herbivory history on Prunus padus and Prunus serotina

152

153 We used historical accessions of P. padus and P. serotina in the herbarium collection of

154 Naturalis Biodiversity Center to produce time-series of insect herbivory in the Netherlands

155 for both hosts. Herbivory was assessed by a method of our own design, as percentage of

156 leaves on a herbarium specimen that showed pre-collection insect damage (post-collection

157 damage by herbarium beetles was recognized and recorded, but not included in the

158 herbivory data). We are aware of the fact that some botanists may preferentially have

159 collected undamaged branches, so these estimates of herbivory are to be treated as

160 conservative. We assessed changes of herbivory over time by Pearson tests on linear

161 correlation coefficients.

162

163 
164 Parasitization of caterpillars

165

166 Within the same $2 \times 2 \mathrm{~km}$ area as mentioned above, we sampled 173 and 110 live

167 caterpillars from 43 P. padus and 32 P. serotina trees, respectively, between May $18^{\text {th }}$ and

168 June $3^{\text {rd }}, 2011$. All caterpillars were reared in individual vials. If a caterpillar

169 metamorphosed into an adult moth or butterfly, it was considered unparasitized. If a

170 parasitoid wasp or fly emerged, the host was considered parasitized. Caterpillars or pupae

171 from which no adult insect had emerged by June $19^{\text {th }}$, were dissected in ethanol or Ringer's

172 solution to determine the presence or absence of parasitoid eggs, larvae, pupae, or adults

173 (Zchori-Fein et al., 2001). When found, these hosts were also considered as parasitized.

174 Models describing the binominal response variable "parasitized" $(\mathrm{Y} / \mathrm{N})$ with combinations

175 and interactions of the following explanatory variables: tree, method, xylosteana, and tree-

176 ID (which was added as a random effect) were created and analysed in R 2.12 .1 ( $R$

177 Development Core Team, 2010). "Tree” was the caterpillar's host plant species (P. padus /

178 P. serotina). "Method" was the way a caterpillar was determined to have been parasitized

179 or not (dissected in ethanol, dissected in Ringer's solution, or reared to adult or parasitoid

180 emergence). "Xylosteana" indicated if the caterpillars belonged to the most commonly

181 encountered species, Archips xylosteana (TRUE) or another species (FALSE). Of the

182 identified caterpillars, all other species were not present in sufficient numbers $(<8)$ for

183 species-level analysis. 
186 Determination of cyanogenic glycosides

187

188 We analysed secondary plant compounds for 57 of the P. padus and 56 of the P. serotina 189 plants for which we sampled herbivores in 2012 (see above). Immediately after each

190 herbivore sampling, we harvested five young leaves and five old leaves from each tree, and

191 kept these in separately labelled bags in a Dewar flask with solid $\mathrm{CO}_{2}$ in the field. All

192 samples were ground under liquid nitrogen and freeze-dried. We carried out NMR-analysis

193 as described previously (Pimenta et al., 2014; Kim et al., 2003; Kim et al., 2010). Briefly,

194 extracts in $\mathrm{CH}_{3} \mathrm{OH}-\mathrm{d} 4$ and $\mathrm{KH}_{2} \mathrm{PO}_{4}$ buffer in $\mathrm{D}_{2} \mathrm{O}$ (1:1) were quantitatively analysed for

195 prunasin and amygdalin, using 1H-NMR spectroscopy on a 500MHz Bruker DMX-500

196 spectrometer (Bruker, Karlsruhe, Germany). Purity of quantitated 1H-NMR signals was

197 evaluated using several two-dimensional NMR experiments. Correlations were investigated

198 between concentrations of each of the cyanogenic glycosides and herbivore load. We

199 treated generalists (category G, see above) and specialists (categories R, P, M, and 0)

200 separately. In view of the high numbers of Yponomeuta evonymellus and Rhopalosiphum

201 padi on some P. padus trees, we log-transformed the specialist herbivore load for P. padus.

202 The relative amounts of cyanogenic glycosides were calculated per sample by taking the

203 integrals in buckets $\delta 5.92$ (for prunasin) and $\delta 5.88+\delta 5.84$ (for amygdalin). Correlations

204 were tested with parametric Pearson's tests for the data on generalists and (in view of the

205 large numbers of samples devoid of specialists) with non-parametric Spearman's tests for 206 the data on specialists. 
209 A specialist herbivore's food preference for the original Sorbus vs. the novel

210 Prunus serotina

211

212 We selected the oligophagous leaf beetle G. quinquepunctata for a case study of host

213 preference. We chose this species because (i) it has very recently (probably in the early

214 1990s) colonized P. serotina in north-central Europe (Klaiber, 1999; Halarewicz \&

215 Jackowski, 2011; Meijer et al., 2012; Mazderek et al., 2015); (ii) it is a specialized species,

216 originally feeding chiefly on rowan, Sorbus aucuparia (Wimmer \& Winkel, 2000; Koch,

217 1992). Within a circle with $6-\mathrm{km}$ radius around Eelde $\left(53^{\circ} 08^{\prime} \mathrm{N}, 6^{\circ} 34^{\prime} \mathrm{E}\right)$, this beetle only

218 feeds on the original native host $S$. aucuparia and the novel introduced P. serotina (not on

219 any other hosts), and is equally abundant on both (Meijer, 2013). In May 2011, 83 adults

220 and 138 larvae were collected from S. aucuparia and 63 adults and 57 larvae were collected

221 from P. serotina, and kept separate by collection locality and host plant. These were used in

222 host choice experiments: one S. aucuparia and one P. serotina branch (with 3-5 leaves each)

223 was placed in a bottle filled with water, which was then placed in the centre of a $0.25 \mathrm{~m}^{3}$

224 cage. Between one and five adults or between two and 10 larvae were selected from one of

225 the live, host-specific collections and placed on the plug in the neck of the bottle. Each

226 experiment was conducted with individuals from only one of the two hosts, and each

227 individual was tested only once. Adults and larvae were not mixed within an experiment.

228 After $21 \mathrm{~h}$, the position for each individual was recorded and the animals were returned to

229 their respective live collections. The test was performed 107 times. Tests were carried out

230 on animals collected within a two-week period and were begun on the date that they were

231 collected. We then tested for host preference using a GLM with binomial distribution. The 
232 model included the fixed factors of original host plant, life stage (larva or adult), interaction

233 between original host plant and life stage, collection date, locality of origin, and cage

234 (multiple cages were used). The effect of each factor was tested by removing one factor and 235 comparing the complete model with the reduced model, and to do this successively with 236 each of the factors, using ANOVA. Host preference in G. quinquepunctata was tested with a 237 proportion test, by comparing the host choices for all animals, depending on their host of 238 origin. All analyses were done in R (R Development Core Team, 2010).

241 Genomic differentiation in host-specific subpopulations of a specialist

242 herbivore

243

244 Using the same G. quinquepunctata specimens from Eelde as above, after finishing the host 245 choice tests, we chose one adult individual from each host plant and obtained full genome 246 sequences from these using paired-end forward-reverse sequencing on an Illumina HiSeq 247 2000. We pooled the data from both G. quinquepunctata sequencing runs and used this for 248 a single de novo assembly. We assembled the data using Abyss (Simpson et al., 2009) with a $249 k$-mer length of 23 and a $k$-mer coverage of 3, values which we optimized using KmerGenie 250 (Chikhi \& Medvedev, 2013). We saved all produced contigs longer than 200bp. We then 251 mapped the data from both samples separately against these contigs using BWA (Li \& 252 Durbin, 2009) at default settings and used Samtools (Li et al., 2009) to call the SNPs in the 253 BWA alignments. We looked up the SNP positions in the alignments for both samples and 
254 filtered based on the following criteria: the positions were both homozygous for different

255 alleles between the samples, had a coverage of at least 10x in each sample, had flanking

256 regions that were at least $100 \mathrm{bp}$ long with a minimum combined coverage of at least $15 \mathrm{x}$

257 with a maximum of 2 heterozygous positions. We identified the contigs containing valid

258 SNP positions by BLASTing them against the GenBank nucleotide database and removing

259 all non-arthropod contigs. Based on the remaining SNPs, we made a random selection of

260128 SNPs (Table S5), all from different contigs, for which we designed primers using the

261 Kraken software (LGCgenomics). Subsequently, in June 2014, again within the same 6-km

262 radius around Eelde, we collected a new set of individuals from both hosts at five localities

263 (Norg-1, Norg-2, Kleibos, Appelbergen, and Noordlaarderbos); 206 from S. aucuparia, and

264173 from P. serotina. We performed DNA extractions on head+thorax using the NucleoMag

26596 Tissue kit (Macherey-Nagel Gmbh \& Co., Düren, Germany) on the KingFisher Flex

266 magnetic particle processor (Thermo Scientific). DNA was diluted to $1 \mathrm{ng} / \mu \mathrm{l}$ and analysed

267 in uniplex on the LGC Genomics SNP-genotyping line according to manufacturer's

268 instructions. SNPs were detected using the KASP technique (Semagn et al., 2014).

269 Genotypes were called using the Kraken software. We discarded five loci that did not yield

270 scorable SNP-patterns and four loci that deviated from Hardy-Weinberg equilibrium,

271 leaving 119 loci. Missing data were scattered over loci and samples and amounted to $2.9 \%$

272 of the total data set. We assessed population differentiation by Analysis of Molecular

273 Variance (AMOVA), as well as by a Structure analysis (Pritchard et al., 2000; Excoffier \&

274 Lischer, 2010). For Structure, standard settings were used and 10 replicates were

275 performed for $\mathrm{K}=2$ to $\mathrm{K}=10$. The results were uploaded to Structure Harvester and a delta $\mathrm{K}$

276 plot was used to determine the number of groups (Earl \& vonHoldt, 2012). We used a 
277 hierarchical AMOVA with host plants nested within localities, and we repeated the same 278 AMOVA on a locus-by-locus basis. 
280 Results

281

282 Sampling herbivore communities on Prunus serotina and Prunus padus

283

284 Our sampling method covered on average, per tree, 258 ( \pm 136 s.d.) and 141 ( \pm 91 s.d.)

285 leaves of $P$. serotina and P. padus, respectively. Given mean fresh weights of $P$. serotina and

286 P. padus leaves of 0.44 and $0.91 \mathrm{~g}$, respectively, the amounts of foliage searched in 5

287 minutes were $113.5 \mathrm{~g}$ and $128.3 \mathrm{~g}$ for P. serotina and P. padus, respectively. After correction

288 for the $1.13 \times$ more foliage searched in P. padus, we found that P. serotina harbors a 4.15-

289 fold lower density but almost two-fold higher species diversity of herbivorous insects

290 (Table 1; Table S1) than P. padus. The higher herbivore load on P. padus is, however, largely

291 due to only two monophagous species, Y. evonymella (Lepidoptera: Yponomeutidae) and $R$.

292 padi (Hemiptera: Aphididae), which usually occur in dense "nests" and "colonies",

293 respectively (Leather, 1985). These two species were found on P. serotina at much lower

294 densities and usually only as single individuals. Almost half of the herbivore specimens

295 found on P. padus belong to these two species. We did not find a difference in the

296 proportions of specialists versus generalists on the native and the non-native host (Fig. 2):

297 both species carried similar (chi-square $=4.13 ; P=0.38$ ) proportions of each of the four

298 categories of host range (G, generalists; R, Rosaceae-specialists; P, Prunus-specialists; M, $P$.

299 padus monophages; and 0, other-mostly Quercus-specialists).

300

301 
302 History of herbivory on Prunus padus and Prunus serotina

303

304 Herbarium records (Table S2) for P. serotina ( $\mathrm{n}=96$; 2817 leaves) showed a more than

305 two-fold increase in herbivory (proportion damaged leaves) from $18.8 \%$ to $40.6 \%$ over the 306 past 170 years $(\mathrm{r}=0.262 ; P=0.0099, \mathrm{df}=94$; Pearson test; Fig. $3 \mathrm{~A})$. For $P$. padus $(\mathrm{n}=222$;

3076612 leaves), herbivory has remained stable at c. $35 \%$ over the past two centuries ( $\mathrm{r}=$ -

308 0.020; $P=0.766$, Pearson test; Fig. 3B). In the most recent year (2013) we found no

309 significant difference between the herbivory in P. padus (40\%) and P. serotina (41\%) (T-

310 test; $P=0.53)$.

313 Parasitization of caterpillars

314

315 The percentages of parasitized caterpillars on both Prunus species were not significantly

316 different (P. padus: 55/173, 32\%; P. serotina: 43/110, 39\%; chi-square $=1.58 ; P=0.21$ ).

317 Tables of explanatory variables and response variables are presented in Table S8. A third of

318 all collected specimens belonged to Archips xylosteana. A test of independence of the

319 explanatory variable tree explaining the response variable "parasitized" was not significant

320 (chi-square $=1.58, \mathrm{df}=1, P=0.20$ ). A full generalized linear model was used to described

321 the response variable "parasitized" as a three-way interaction between "tree", "method",

322 and "xylosteana". The full model was not significant, and after simplifying the model by

323 steps, the only explanatory variable to affect parasitization significantly was the method 
324 used to determine if a specimen was infected by a parasitoid $(P<0.01)$. The identified 325 parasitoids mostly belonged to Ichneumonidae, Braconidae, and Tachinidae.

\section{Determination of cyanogenic glycosides}

In the NMR-analyses (Table S3), we found that the concentration of cyanogenic glycosides

331 (prunasin and amygdalin combined) per unit leaf dry weight is similar in both Prunus

332 species. Mean concentrations in young and old leaves differed by $<5 \%$ in each plant

333 species. In both plant species, the ratio prunasin : amygdalin was c. $3: 1$. Generalist and

334 specialist herbivores showed different relations with cyanogenic glycoside concentrations,

335 and the responses to prunasin differed from those to amygdalin. Specifically, we found that

336 the generalist herbivore load was not correlated with prunasin $(\mathrm{R}=-0.08, P=0.39$, both in

337 P. prunus and P. serotina), but increased with amygdalin concentration $(\mathrm{R}=0.24$ and 0.36 ;

$338 P=0.01$ and 0.0001 , respectively, in P. padus and P. serotina), whereas the specialist

339 herbivore load increased with prunasin concentration, and decreased with amygdalin

340 concentration, but significantly so only in P. padus (of which the amygdalin relationship

341 would lose significance after Bonferroni correction; see statistical test results given in Fig. $3424)$. 
345 A specialist herbivore's food preference for the original Sorbus vs. the novel

346 Prunus serotina

347

348 At the end of the host choice experiment, 52\% of all experimental G. quinquepunctata were 349 present on one of the host plants. Individuals collected on S. aucuparia showed a significant 350 preference for $S$. aucuparia $(69.7 \pm 3.1 \%)$ over $P$. serotina $(P<0.0001)$. However,

351 individuals collected on P. serotina showed no significant preference for either host. Similar

352 patterns were found in both adults and larvae: Individuals from S. aucuparia preferred 353 their original host $(75.9 \pm 7.0 \%$ for adults, $P<0.0001$, and $65.9 \pm 9.0 \%$ for larvae, $P=$ 354 0.0003); individuals from $P$. serotina showed no preference (58.7 $\pm 9.1 \%$ for adults, $P=$ 3550.2077 , and $57.9 \pm 14.3 \%$ for larvae, $P=0.2893$ ). Full test results are available in Table S7.

358 Genomic differentiation in host-specific subpopulations of a specialist 359 herbivore

361 Illumina sequencing of a G. quinquepunctata larva from S. aucuparia gave 157,327,896 362 reads, and 191,340,606 reads were obtained from an adult beetle found on P. serotina. The 363 de-novo assembly with Abyss resulted in 438,237 contigs longer than $200 \mathrm{bp}$. The data 364 were deposited in the NCBI short read archive under BioProject accession code:

365 PRJNA277307. A total of 729 usable SNPs were obtained from the SNP discovery. To assess 366 genetic differentiation in both host-specific subpopulations, we genotyped 379 individuals 
367 from both hosts at each of five localities, for the selected 119 SNP loci (Table S4). Our

368 Structure analysis (SI Text S1) failed to detect overall genetic differentiation between the 369 populations on both host plants: the highest posterior probability was for $K=2$, but these 370 two groups did not correspond with host plant nor with locality. The hierarchical AMOVA

371 with host plants nested within localities, showed significant $(P<0.01)$ differentiation

372 between host plants in each locality. On a locus-by-locus basis, the AMOVA revealed 13 loci

373 that were significantly differentiated between the two subpopulations from P. serotina and

374 S. aucuparia, two of which remained significant after strict Bonferroni correction (Table

375 S6). The distribution of per-locus pairwise (Prunus-Sorbus) $\mathrm{F}_{\mathrm{ST}}$ values (Fig. 5) also shows

376 that at least two loci are outliers. Homology searches in Genbank for these SNP loci yielded 377 no matches with genes of known function. 


\section{Discussion}

380

381 Our inventories show that the invasive P. serotina in the Netherlands harbours a

382 surprisingly rich community of herbivores. Although the densities were lower than on

383 native $P$. padus, the species diversity was greater. Also, contrary to expectations, the $P$.

384 serotina herbivore community contained similar proportions of specialists versus

385 generalists as the one on P. padus. The only species strikingly absent from $P$. serotina were

386 two abundant P. padus monophages, Y. evonymellus and R. padi. Consistent with Leather

387 (1985), both species were responsible for more than two thirds of all insects found feeding

388 on P. padus, whereas they occurred on P. serotina only in small numbers (we found only a

389 single $Y$. evonymellus caterpillar and a single $R$. padi colony on P. serotina). Nonetheless,

390 laboratory data (Kooi et al., 1991) and field data from Poland (Karolewski et al., 2014)

391 suggest that at least Y. evonymellus has the potential to feed on P. serotina. Karolewski et al.

392 (2014) state that in Poland, the latter species has progressed from avoiding P. serotina

393 altogether to feeding and developing on it massively over the past decade. The near-

394 absence from P. serotina of this herbivore in our study area suggests that a similar

395 colonization event may not yet have taken place, but this may change in the near future,

396 possibly aided by long-distance gene flow from the populations in Poland. Another striking

397 difference between both hosts is the relatively large numbers of non-Rosaceae specialists

398 on P. serotina. While some of these may be accidental "tourists", the high number of

399 individuals for some of these species (e.g., the Quercus-specialist Harpocera thoracica) is

400 noteworthy. 
401 These results add to a body of data on insect herbivory on native versus non-native plants

402 (reviewed in, e.g., Liu \& Stiling, 2006; Colautti et al., 2004; Meijer, 2013). Although these

403 studies tend to show that introduced plant species, especially those with powerful chemical

404 defences, are poor hosts for native herbivores, exceptions have also been found of

405 introduced species hosting a larger number of species than closely-related native plants

406 (Novotny et al., 2003). The rich herbivore community on non-native P. serotina, and

407 especially the high number of specialist species, fits with the observation that the food web

408 supported by a non-native plant expands as time since initial introduction increases

409 (Brändle et al., 2008). Although P. serotina was introduced into Europe earlier (Schütz,

410 1988), it only became common in the $20^{\text {th }}$ century (Starfinger et al., 2003). Its increasing

411 abundance in Dutch ecosystems over the past 80 years may have been the phase during

412 which most of the herbivore community has built up. Indeed, while our study of leaf

413 damage in herbarium specimens cannot reveal the diversity of herbivores, it does show

414 that herbivore damage, and therefore perhaps herbivore load, has gradually doubled over

415 this period, while that on P. padus has not changed. Today, at least based on our herbarium

416 records, herbivory levels in both plant species appear to be similar (despite the lower

417 herbivore load that we found in our inventory for P. serotina-see above).

418 In theory, the rapid assembly of this community may have been aided by the presence of an

419 enemy-free space for the insect herbivores. If local parasitoids, for example, are not

420 adapted to using $P$. serotina volatiles as a cue for attraction to a possible patch in which to

421 find hosts, this may have helped the establishment of herbivore populations on the

422 introduced plant (Feder, 1995; Harvey \& Fortuna, 2012). Indeed, Karolewski et al. (2014)

423 found reduced parasitization of one species, Y. evonymella on P. serotina. However, we find 
424 that current attack rates of caterpillars by parasitoids do not differ between P. padus and $P$.

425 serotina.

426 After an initial period of reduced specialist herbivory in the non-native range, $P$. serotina

427 may have shifted its investment in chemical defences in favour of those aimed at

428 generalists (Joshi \& Vrieling, 2005). Cyanogenic glycosides are generally considered to be

429 systemic, non-inducible, and energetically cheap chemical defences aimed primarily at

430 generalist herbivores (Gleadow \& Møller, 2014). However, our phytochemical data suggest

431 that, in P. padus (and, less clearly, in P. serotina), the Rosaceae-specific compound

432 amygdalin has a positive relationship with generalist load but a negative one with specialist

433 load, whereas the more widespread compound prunasin has a positive correlation with

434 specialist herbivore load, while lacking any clear relation with generalist load. It would be

435 tempting to compare the levels and ratios of prunasin and amygdalin in today's P. serotina

436 populations in the Netherlands with those reported for the native American population.

437 However, we only have access to a single American study (Santamour, 1998), which,

438 moreover, employed somewhat different methods (see below), so we do so with

439 considerable hesitation. Santamour (1998) reported a summertime HCN production in

440 native American P. serotina corresponding to $29.6 \mathrm{mg}$ cyanogenic glycosides per $\mathrm{g}$ fresh

441 leaf material (see SI Text S2). In an earlier study of 22 Dutch P. serotina trees (Pimenta et

442 al., 2014), we found on average $30.4 \mathrm{mg}$ cyanogenic glycosides per mg dry leaf material. As

443 P. serotina dry leaf weight is $36 \%$ of fresh leaf weight (see SI Text S2), this might suggest

444 that total cyanogenic glycoside content in the invaded range could be about two- to

445 threefold lower than in North America. Also, Santamour found prunasin : amygdalin

446 proportions of $22: 1$, whereas we found a ratio of $3: 1$. In the Dutch P. serotina, prunasin 
447 investment might therefore have decreased, with amygdalin content remaining more or

448 less constant. Since both the absolute and relative amounts of prunasin and amygdalin

449 content have a genetic basis (Santamour, 1998), these results might indicate that

450 cyanogenic glycoside defence has, after the introduction into Europe, adapted to the novel

451 herbivore communities. With a mean age at first reproduction of only 5.2 years (Deckers et

452 al., 2005) and evidence, in general, of rapid evolution of defence in invasive plants (Felker-

453 Quinn et al., 2013), such a quick evolutionary change is not implausible. However, since

454 Santamour (1998), Pimenta et al. (2014) and the present study appear to be the only

455 available quantifications of prunasin and amygdalin in P. serotina, and since the range of

456 phenotypic plasticity in cyanogenic glycoside content is unknown, more data, with more

457 comparable methods, are needed before this conclusion can be substantiated. Moreover,

458 we stress that our results and their discussion refer only to the cyanogenic potential

459 (HCNp), whereas the true defence potential is a combination of HCNp and HCNc,

460 cyanogenic capacity, which is a function of glucosidase presence and activity. Since the

461 latter is unknown in this study, we implicitly assume that HCNp is an indicator for

462 cyanogenic defence, which may only be partly true and is known to differ between

463 specialists and generalists (Ballhorn et al. 2010a).

464 The accumulation of the herbivore community on P. serotina may also have involved

465 evolutionary processes within the insect community itself. One possibility is that all

466 present-day herbivores were able to feed and reproduce on P. serotina from the moment

467 the new host was introduced. However, this would not explain the slow increase in

468 herbivory that our herbarium data show: highly mobile insects with short generation times

469 would have established on the new host instantaneously, rather than gradually. It is 
470 therefore likely that adaptive evolution in the herbivores played an important role in the

471 assembly of this community over time.

472 As a possible example of this scenario, we performed a case study on one specialist

473 herbivore, the leaf beetle G. quinquepunctata, which has recently colonized $P$. serotina from

474 its original host, rowan (S. aucuparia). We find indications of weak differentiation in host

475 preference and SNP-loci on Sorbus- versus Prunus-derived beetle individuals. We found

476 that individuals collected on Sorbus retained a significant host preference for this host,

477 whereas beetles collected from Prunus showed no preference for Prunus over Sorbus. We

478 found the same host preference in adults and larvae, although presumably host choice is

479 made mostly in the mobile, adult stage. While these results do not necessarily imply genetic

480 differentiation, as learning may be involved as well (Salloum et al., 2011), our SNP-analysis

481 does show indications of weak genetic differentiation, with several loci showing

482 divergence, and potentially linked to regions that are under disruptive, host-imposed

483 selection. In other words, the introduced P. serotina may have selected for weak, incipient

484 divergence (Vellend et al., 2007; Nosil \& Feder, 2011) in this particular herbivore. Whether

485 such selection will allow further sympatric speciation, in this herbivore or others, depends

486 not only on the different selection regimes imposed by the different host plants, but also on

487 the mount of gene-flow between the populations feeding on the two hosts (Nosil \& Feder,

488 2011).

489 Overall, our results indicate that, since its introduction, a rich and diverse herbivore

490 community has accumulated on P. serotina. It is possible that evolutionary adaptations in

491 these herbivores as well as in the plant itself have played an important role in shaping this 
492 community. Adaptation may have involved niche widening in generalist herbivores,

493 incipient genetic divergence in specialists, as well as adjustments of chemical defences in

494 the host plant.

495

496 These results may have implications for invasive species management. It may be expected

497 that the gradual evolutionary integration of a novel plant species in a native herbivore food

498 web may eventually reduce its invasive character to the point where it attains the status of

499 non-harmful, naturalized neophyte. Whether this will happen in the case of P. serotina

500 depends on a number of factors. In this paper, we dealt with herbivorous insects only,

501 whereas plant demographics are affected by a much broader spectrum of natural enemies.

502 Reinhart et al. (2003) and Van der Putten (2000) suggested that its invasiveness may be

503 more due to an absence of belowground interactions (with the Prunus-pathogenic fungus

504 Pythium, for example) than aboveground interactions. However, preliminary studies in the

505 Netherlands indicate the presence of local Pythium populations that are powerful in

506 attacking introduced P. serotina (Tamis \& van der Klugt, pers. comm.). Furthermore,

507 Ballhorn et al. (2010b) and Ballhorn (2011) found that in cyanogenic plants a trade-off

508 exists between defence against herbivores and against fungal pathogens, which is an

509 additional complication not yet considered. A final point of concern is the intensity of the

510 regime of natural selection. Presently, manual control of mature P. serotina in many

511 European habitats is reducing the continued exposure of the host to its potential

512 herbivores. On the basis of the results presented here, we would like to caution that this

513 might have the adverse effect of a consequent slowing down of processes of adaptation,

514 and a delay in the decline of the invasive character of $P$. serotina. 
515 


\section{Acknowledgments}

517

518 The following experts helped with insect identifications: Theodoor Heijerman (Coleoptera:

519 Curculionoidea), Willem Ellis (leaf miners), Marja van der Straten (Lepidoptera), Erik van

520 Nieukerken and Camiel Doorenweerd (Lepidoptera), Ping-Ping Chen (Hemiptera), and

521 Kees van Achterberg (Hymenoptera). Ruud Luntz (Natuurmonumenten) and Hubert Kivit

522 (PWN) provided important details on P. serotina distribution in Zuid-Kennemerland. Luc

523 Willemse, Kees Koops, René Glas, Kees van den Berg, Jekaterina Tkacova, Daniel Cisneros

524 Torres, Renda Remmerswaal, Esther van der Meer, and Bertie-Joan van Heuven helped in

525 the lab. Leni Duistermaat, Wil Tamis, and Rinny Kooi provided details on P. serotina and its

526 herbivores. Rienk Apperloo, Sjoerd Hobma, Anne Posthumus, and Marlijn Sterenborg

527 helped with the experiments on Gonioctena host preference. Rick de Graaf, Stephen

528 Pieterman, and Carla Stegehuis assisted in the de novo assembly. The photograph in Fig. 1

529 was kindly provided by Ruud Lardinois of Stichting Kritisch Bosbeheer, Dieren, the

530 Netherlands. 


\section{Competing Interests}

533 Marco Flohil is an employee of ServiceXS, a company providing DNA services such as

534 reported in this paper. 


\section{References}

$536 \quad 0$ Anonymous (2014) HELA-PROJECT (Heideherstel op Landduinen). Available:

537 http://ec.europa.eu/environment/life/project/Projects/index.cfm?fuseaction=hom

538 e.showFile\&rep=poster\&fil=HELA_infobord.pdf.

$539 \quad \circ$ Bakker J (1963) De ontwikkelingsgeschiedenis van Prunus serotina Ehrh. in

$540 \quad$ Nederland. Nederlands Bosbouwkundig Tijdschrift, 35, 201-206.

$541 \quad \circ$ Ballhorn DJ, Kautz S, Lieberei R (2010a) Comparing responses of generalist and

$542 \quad$ specialist herbivores to various cyanogenic plant features. Entomologia

543 Experimentalis et Applicata, 134, 245-259.

$544 \quad$ ○ Ballhorn DJ, Pietrowski A, Lieberei R (2010b) Direct trade-off between cyanogenesis

545 and resistance to a fungal pathogen in lima bean (Phaseolus lunatus L.). Journal of

$546 \quad$ Ecology, 98, 226-236.

$547 \quad \circ$ Ballhorn DJ (2011). Constraints of simultaneous resistance to a fungal pathogen and

548 an insect herbivore in lima bean (Phaseolus lunatus L.). Journal of Chemical Ecology,

$549 \quad 37,141-144$.

$550 \quad 0$ Blackburn TM, Lockwood JL, Cassey P (2009) Avian Invaders: The Ecology and

$551 \quad$ Evolution of Exotic Birds. Oxford University Press, Oxford.

$552 \quad 0 \quad$ Blossey B, Nötzold R (1995) Evolution of increased competitive ability in invasive

553 nonindigenous plants - a hypothesis. Journal of Ecology, 83, 887-889.

554 ○ Bortiri E, Oh SH, Jiang J, Baggett S, Granger A, Weeks C, Buckingham M, Potter D,

555 Parfitt DE (2001) Phylogeny and systematics of Prunus (Rosaceae) as determined by

556 sequence analysis of ITS and the chloroplast trnL-trnF spacer DNA. Systematic

557 Botany, 26, 797-807. 
$558 \bigcirc$ Boucault J (2009) Influence de la macrofaune (mammifères, oiseaux, insectes) sur la

559 dynamique invasive du cerisier tardif (Prunus serotina Ehrh.) en système forestier

560 tempéré. Université de Picardie Jules Verne, Amiens, France.

561 Brändle M, Kühn I, Klotz S, Belle C, Brandl R (2008) Species richness of herbivores

562 on exotic host plants increases with time since introduction of the host. Diversity

563 and Distributions, 14, 905-912.

$564 \bigcirc$ Butchart SHM, Walpole M, Collen B, van Strien A, Scharlemann JPW, Almond REA,

565 Baillie JEM, Bomhard B, Brown C, Bruno J, Carpenter KE, Carr GM, Chanson J,

566 Chenery AM, Csirke J, Davidson NC, Dentener F, Foster M, Galli A, Galloway JN,

567 Genovesi P, Gregory RD, Hockings M, Kapos V, Lamarque JF, Leverington F, Loh J,

568 McGeoch MA, McRae L, Minasyan A, Morcillo MH, Oldfield TEE, Pauly D, Quader S,

569 Revenga C, Sauer JR, Skolnik B, Spear D, Stanwell-Smith D, Stuart SN, Symes A,

570 Tierney M, Tyrrell TD, Vié JC, Watson R (2010) Global biodiversity: indicators of

$571 \quad$ recent declines. Science, 328, 1164-1168.

$572 \quad \circ \quad$ Chikhi R, Medvedev P (2013) Informed and automated $k$-mer size selection for

573 genome assembly. Bioinformatics, 30, 31-37.

$574 \quad$ Colautti R, Ricciardi A, Grigorovich I, MacIsaac HJ (2004) Is invasion success

575 explained by the enemy release hypothesis? Ecology Letters, 7, 721-733.

$576 \quad \circ \quad$ Deckers B, Verheyen K, Hermy M, Muys B (2005) Effects of landscape structure on

577 the invasive spread of black cherry Prunus serotina in an agricultural landscape in

578 Flanders, Belgium. Ecography, 28, 99-109.

579 ○ Dostál P, Müllerová J, Pysek P, Pergl J, Klinerová T (2013) The impact of an invasive 580 plant changes over time. Ecology Letters, 16, 1277-1284. 
581 Earl DA, vonHoldt BM (2012) STRUCTURE HARVESTER: a website and program for

582 visualizing STRUCTURE output and implementing the Evanno method. Conservation

583 Genetics Resources, 4, 359-361.

$584 \quad \circ \quad$ Excoffier L, Lischer HEL (2010) Arlequin suite ver. 3.5: A new series of programs to

585 perform population genetics analyses under Linux and Windows. Molecular Ecology

$586 \quad$ Resources, 10, 564-567.

$587 \quad \circ$ Feder JL (1995) The effects of parasitoids on sympatric host races of Rhagoletis

588 pomonella (Diptera: Tephritidae). Ecology, 76, 801-813.

$589 \quad$ Felker-Quinn E, Schweitzer JA, Bailey JK (2013) Meta-analysis reveals evolution in

590 invasive plant species but little support for Evolution of Increased Competitive

$591 \quad$ Ability (EICA). Ecology and Evolution, 3, 739-751.

$592 \quad$ F Fitzgerald TD (2008) Larvae of the fall webworm, Hyphantria cunea, inhibit

593 cyanogenesis in Prunus serotina. Journal of Experimental Biology, 211, 671-677.

$594 \quad$ ○ Fotopoulos L (2000) Vergleich der Phytophagenfauna am Beispiel der Rüsselkäfer

595 (Curculionidae, Coleoptera) an zwei einheimischen und zwei fremdländischen

596 Baumarten in Berlin. Technische Universität Berlin, Berlin, Germany.

$597 \quad \circ$ Gleadow RM, Møller BL (2014) Cyanogenic glycosides: synthesis, physiology, and

598 phenotypic plasticity. Annual Review of Plant Biology, 65, 155-185.

$599 \quad$ G Glowka L, Burhenne-Guilmin F, Synge H (1994) A guide to the Convention on

600 Biological Diversity. IUCN, Gland.

$601 \quad$ Godefroid S, Phartyal SS, Weyembergh G, Koedam N (2005) Ecological factors

602 controlling the abundance of non-native invasive black cherry (Prunus serotina) in 
deciduous forest understory in Belgium. Forest Ecology and Management, 210, 91-

604 105.

$605 \quad$ G Gurevitch J, Padilla DK (2004) Are invasive species a major cause of extinctions?

606 Trends in Ecology and Evolution, 19, 470-474.

607 Halarewicz A, Jackowski J (2011) Leaf damage of the black cherry, Prunus serotina Ehrh., by the leaf beetle, Gonioctena quinquepunctata Fabr.: an accidental foraging 609

610 on a neophytic host, or an established trophic link? Polish Journal of Ecology, 59, 589-597.

- Harvey JA, Fortuna TM (2012) Chemical and structural effects of invasive plants on herbivore-parasitoid/predator interactions in native communities. Entomologia Experimentalis et Applicata, 144, 14-26.

615

616 143. microheterogenity in black cherry. Plant Physiology, 119, 1535-1546. unite the European Union? Science, 324, 40-41.

○ Joshi J, Vrieling K (2005) The enemy release and EICA hypothesis revisited: incorporating the fundamental difference between specialist and generalist herbivores. Ecology Letters, 8, 704-714. 
insects. Acta Oecologica, 53, 19-32.

627 Karolewski P, Jagodziński, Giertych MJ, Łukowski A, Baraniak E, Oleksyn J (2014)

628 Invasive Prunus serotina - a new host for Yponomeuta evonymellus (Lepidoptera:

629 Yponomeutidae)? European Journal of Entomology, 111, 227-236.

$630 \quad$ Keane RM, Crawley MJ (2002) Exotic plant invasions and the enemy release

631 hypothesis. Trends in Ecology and Evolution, 17, 164-170.

632 Kim HK, Choi YH, Chang WT, Verpoorte R (2003) Quantitative analysis of ephedrine

633 analogues from Ephedra species using 1H-NMR. Chemical and Pharmaceutical

$634 \quad$ Bulletin, 51, 1382-1385.

635 Kim HK, Choi YH, Verpoorte R (2010) NMR-based metabolomic analysis of plants.

$636 \quad$ Nature Protocols, 5, 536-548.

637 Klaiber C (1999) Massenvermehrung des Blattkäfers Gonioctena quinquepunctata an

638 der spätblühenden Traubenkirsche. Der Wald, 25, 1351-1352.

639 Van Kleunen M, Dawson W, Essl F, Pergl J, Winter M, Weber E, Kreft H, Weigelt P,

640 Kartesz J, Nishino M, Antonova LA, Barcelona JF, Cabezas FJ, Cárdenas D, Cárdenas-

641 Toro J, Castaño N, Chacón E, Chatelain C, Ebel AL, Figueiredo E, Fuentes N, Groom QJ,

642 Henderson L, Inderjit, Kupriyanov A, Masciadri S, Meerman J, Morozova O, Moser D,

643 Nickrent DL, Patzelt A, Pelser PB, Baptiste MP, Poopath M, Schulze M, Seebens H, Shu

644 WS, Thomas J, Velayos M, Wieringa JJ, Pyšek P (2015) Global exchange and

645 accumulation of non-native plants. Nature, 525, 100-103.

$646 \quad$ Koch K (1992) Chrysomelidae. Die Käfer Mitteleuropas, E3, 51-138. 
647 Kooi RE, van de Water TPM, Herrebout WM (1991) Food acceptance by a

648 monophagous and an oligophagous insect in relation to seasonal changes in host

649 plant suitability. Entomologia Experimentalis et Applicata, 59, 111-122.

$650 \quad$ Korringa P (1947) Nachtelijk bezoek aan Prunus serotina. De Levende Natuur, 50, $65126-29$.

652 ○ Leather SR (1985) Does the bird cherry have its "fair share" of insect pests? An

653 appraisal of the species-area relationships of the phytophagous insects associated 654 with British Prunus species. Ecological Entomology, 10, 43-56.

655 ㄴ Hi H, Durbin R (2009) Fast and accurate short read alignment with Burrows656 Wheeler transform. Bioinformatics, 25, 1754-1760.

657 Li H, Handsaker B, Wysoker A, Li H, Handsaker B, Wysoker A, Fennell T, Ruan J, 658 Homer N, Marth G, Abecasis G, Durbin R, 1000 Genome Project Data Processing 659 Subgroup (2009) The sequence alignment/map format and SAMtools.

660 Bioinformatics, 25, 2078-2079.

661 Liu H, Stiling P (2006) Testing the enemy release hypothesis: a review and meta662 analysis. Biological Invasions, 8, 1535-1545.

$663 \quad \circ \quad$ Mazderek E, Łukowski A, Giertych MJ, Karolewski P (2015) Influence of native and 664 alien Prunus species and light conditions on performance of the leaf beetle 665 Gonioctena quinquepunctata. Entomologia Experimentalis et Applicata, 155, 193666205.

$667 \quad \circ \quad$ Meijer K (2013) Native versus non-native; the interplay between native insects and 668 non-native plants. Rijksuniversiteit Groningen, Groningen, the Netherlands. 
669 Meijer K, Smit C, Beukeboom LW, Schilthuizen M (2012) Native insects on non-

670 native plants in The Netherlands: curiosities or common practice? Entomologische $671 \quad$ Berichten, 72, 288-293.

$672 \quad$ Moraal LG (1988) Misoogst van Prunus avium zaad door aantastingen van de 673 kersenpitkever, Furcipus rectirostris L. Nederlands Bosbouwkundig Tijdschrift, 60, $674 \quad 4-11$.

$675 \quad$ Nosil P, Feder JL (2011) Genomic divergence during speciation: causes and 676 consequences. Philosophical Transactions of the Royal Society B, 367, 332-342.

677 Novotny V, Miller SE, Cizek L, Leps J, Janda M, Basset Y, Weiblen GD, Darrow K 678 679 680 716. (2003) Colonising aliens: caterpillars (Lepidoptera) feeding on Piper aduncum and P. umbellatum in rainforests of Papua New Guinea. Ecological Entomology, 28, 704(Ehrh.) within forest community and open habitat. Electronic Journal of the Polish Agricultural University, 9, 5.

○ Nyssen B, den Ouden J, Verheyen K, Schmitz P (2013) Amerikaanse vogelkers: van bospest tot bosboom. KNNV, Zeist.

○ Pearse IS, Hipp AL (2014) Native plant diversity increases herbivory to non-natives.

691 Proceedings of the Royal Society B, 281, 20141841.

○ Pimenta L, Schilthuizen M, Verpoorte R, Choi YH (2014) Quantitative analysis of amygdalin and prunasin in Prunus serotina Ehrh. using 1H NMR spectroscopy. Phytochemical Analysis, 25, 122-126. 
692 O Prentis PJ, Wilson JRU, Dermontt EE, Richardson DM, Lowe AJ (2008) Adaptive

693 evolution in invasive species. Trends in Plant Science, 13, 288-294.

694 Pritchard JK, Stephens M, Donnelly P (2000) Inference of population structure using

695 multilocus genotype data. Genetics, 155, 945-959.

$696 \quad$ R Developent Core Team (2010) R: a language and environment for statistical

697 computing. R Foundation for Statistical Computing, Vienna. Available:

698 http://www.r-sprojects.org; 2010.

699 Reinhardt F, Herle M, Bastiansen F, Streit B (2003) Economic Impact of the Spread of

700 Alien Species in Germany. R+D Project 20186211 (UFOPLAN). J.W. Goethe University,

$701 \quad$ Frankfurt, Germany.

702 Reinhart KO, Packer A, van der Putten WH, Clay K (2003) Plant-soil biota

703 interactions and spatial distribution of black cherry in its native and invasive ranges.

$704 \quad$ Ecology Letters, 6, 1046-1050.

705 Rodriguez-Cabal MA, Williamson M, Simberloff D (2013) Overestimation of

706 establishment success of non-native birds in Hawaii and Britain. Biological

$707 \quad$ Invasions, 15, 249-252.

708 Salloum AV, Colson V, Marion-Poll F (2011) Appetitive and aversive learning in

709 Spodoptera littoralis larvae. Chemical Senses, 36, 725-731.

$710 \quad$ o Santamour FS (1998) Amygdalin in Prunus leaves. Phytochemistry, 47, 1537-1538.

$711 \quad$ Schütz PR (1988) Prunus serotina and P. virginiana, a report of a confusing story.

712 Nederlands Bosbouwkundig Tijdschrift, 60, 306-312. 
713 S Semagn K, Babu R, Hearn S, Olsen M (2014) Single nucleotide polymorphism

714 genotyping using Kompetitive Allele Specific PCR (KASP): overview of the

715 technology and its application in crop improvement. Molecular Breeding, 33, 1-14.

716 Simberloff D (2011) Non-natives: 141 scientists object. Nature, 475, 36.

717 Simberloff D, Gibbons L (2004) Now you see them, now you don't! - Population

718 crashes of established introduced species. Biological Invasions, 6, 161-172.

719 Simpson JT, Wong K, Jackman SD, Schein JE, Jones SJ, Birol I (2009) ABySS: a parallel

720 assembler for short read sequence data. Genome Research, 19, 1117-1123.

721 Starfinger U. Kowarik I, Rode M, Schepker H (2003) From desirable ornamental

722 plant to pest to accepted addition to the flora? - the perception of an alien tree

723 species through the centuries. Biological Invasions, 5, 323-335.

$724 \quad$ Swain E, Li CP, Poulton JE (1991) Development of the potential for cyanogenesis in

725 maturing black cherry (Prunus serotina Ehrh.) fruits. Plant Physiology, 98, 1423-

7261428.

727 Tamis WLM, Van't Zelfde M, Van der Meijden R, Bekker RM, Ozinga WA, Odé B,

728 Hoste I (2005) Annex: Standaardlijst van de Nederlandse flora 2003. Gorteria

$729 \quad$ Supplement, 6, 135-229.

$730 \quad$ Van der Putten WH (2000) Pathogen-driven forest diversity. Nature, 404, 232-233.

$731 \quad$ Van Nieukerken EJ, Mutanen M, Doorenweerd C (2011) DNA barcoding resolves

732 species complexes in Stigmella salicis and S. aurella species groups and shows

733 additional cryptic speciation in S. salicis (Lepidoptera: Nepticulidae). Entomologisk

$734 \quad$ Tidskrift, 132, 235-255. 
$735 \quad$ ○ Vellend M, Harmon LJ, Lockwood JL, Mayfield MM, Hughes AR, Wares JP, Sax DF

736 (2007) Effects of exotic species on evolutionary diversification. Trends in Ecology and Evolution, 22, 481-488.

$738 \quad$ Whitney KD, Gabler CA (2008) Rapid evolution in introduced species, 'invasive 739 traits' and recipient communities: challenges for predicting invasive potential.

740 Diversity and Distributions, 14, 569-580.

$741 \quad$ Williamson M (1996) Biological Invasions. Chapman \& Hall, London.

$742 \quad \circ$ Williamson M, Fitter A (1996) The varying success of invaders. Ecology, 77, 16617431666.

$744 \quad$ Wimmer W, Winkel W (2000) Zum Auftreten von Gonioctena quinquepunctata 745 (Fabr.) (Coleoptera: Chrysomelidae) an Prunus serotina Ehrh. und in der 746 Nestlungsnahrung höhlenbrütender Singvögel im Emsland. Braunschweiger $747 \quad$ Naturkundliche Schriften, 6, 131-138.

748 ○ Winkelman J (2005) Voortgang bij inburgeren? Struikhaantjes rond Ootmarsum. $749 \quad$ Veelpoot, 16, 7-9.

$750 \quad$ Zangerl AR, Berenbaum MR (2005) Increase in toxicity of an invasive weed after 751 reassociation with its coevolved herbivore. Proceedings of the National Academy of $752 \quad$ Sciences USA, 102, 15529-15532.

$753 \quad$ Zchori-Fein E, Gottlieb Y, Kelly SE, Brown JK, Wilson JM, Karr TL, Hunter MS (2001)

754 A newly discovered bacterium associated with parthenogenesis and a change in host 755 selection behavior in parasitoid wasps. Proceedings of the National Academy of $756 \quad$ Sciences USA, 98, 12555-12560. 
757 ○ Żmuda M, Karolewski P, Giertych MJ, Zytkowiak R, Bakowski M, Grzebyta J, Oleksyn

$758 \quad J$ (2008) The effect of light conditions on leaf injury in underbrush shrubs caused by 759 leaf-eating insects. Acta Scientiarum Polonorum Silvarum Colendarum Ratioet

$760 \quad$ Industria Lignaria, 7, 47-57. 


\section{Figures}

762

763

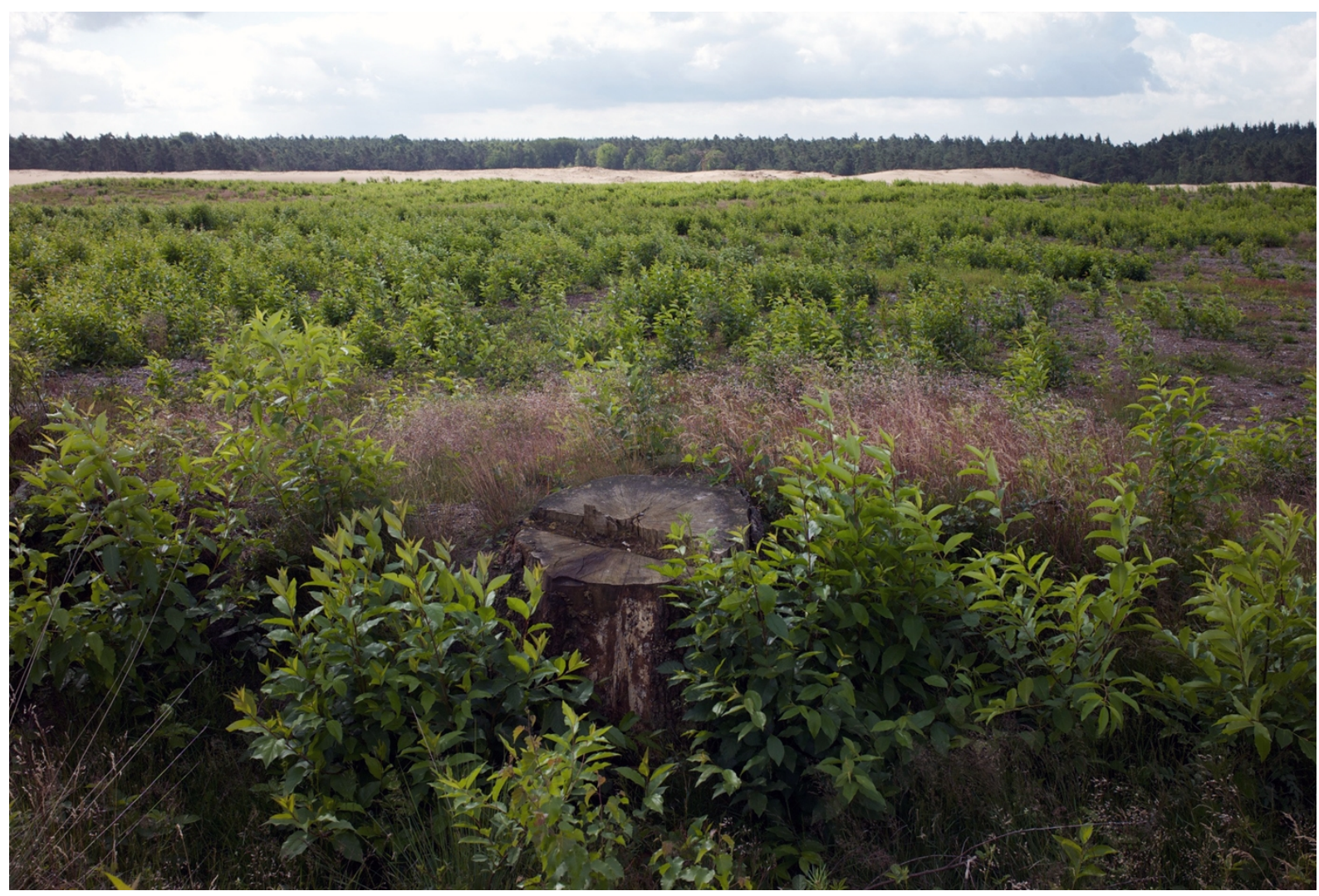

764 Figure 1. In open habitats, such as this moorland in the Netherlands, Prunus serotina may

765 spread invasively, as this carpet of seedlings shows. (photo copyright: Kritisch Bosbeheer). 


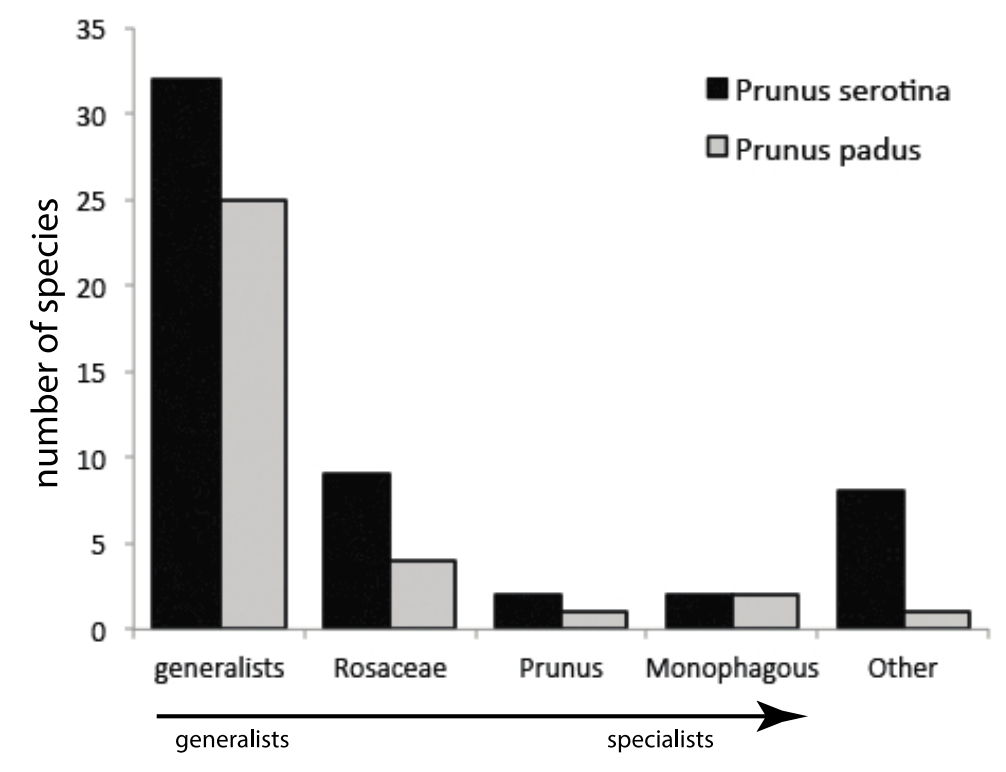

767 Figure 2. Numbers of species from different categories of generalist and specialist insect 768 herbivores sampled from Prunus padus and Prunus serotina. 

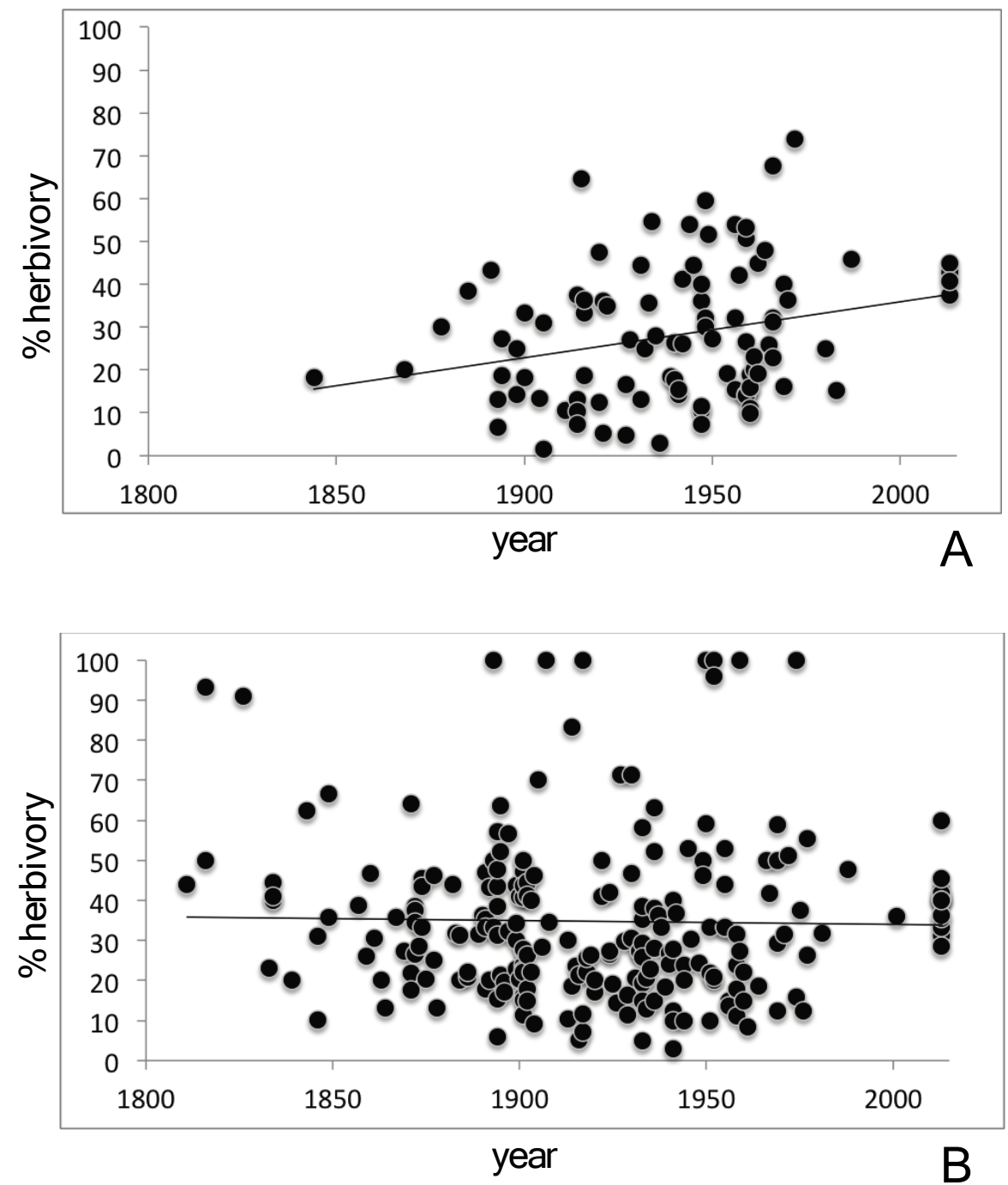

770 Figure 3. Herbivory over time as derived from herbarium records; A, Prunus serotina; B,

771 Prunus padus. 

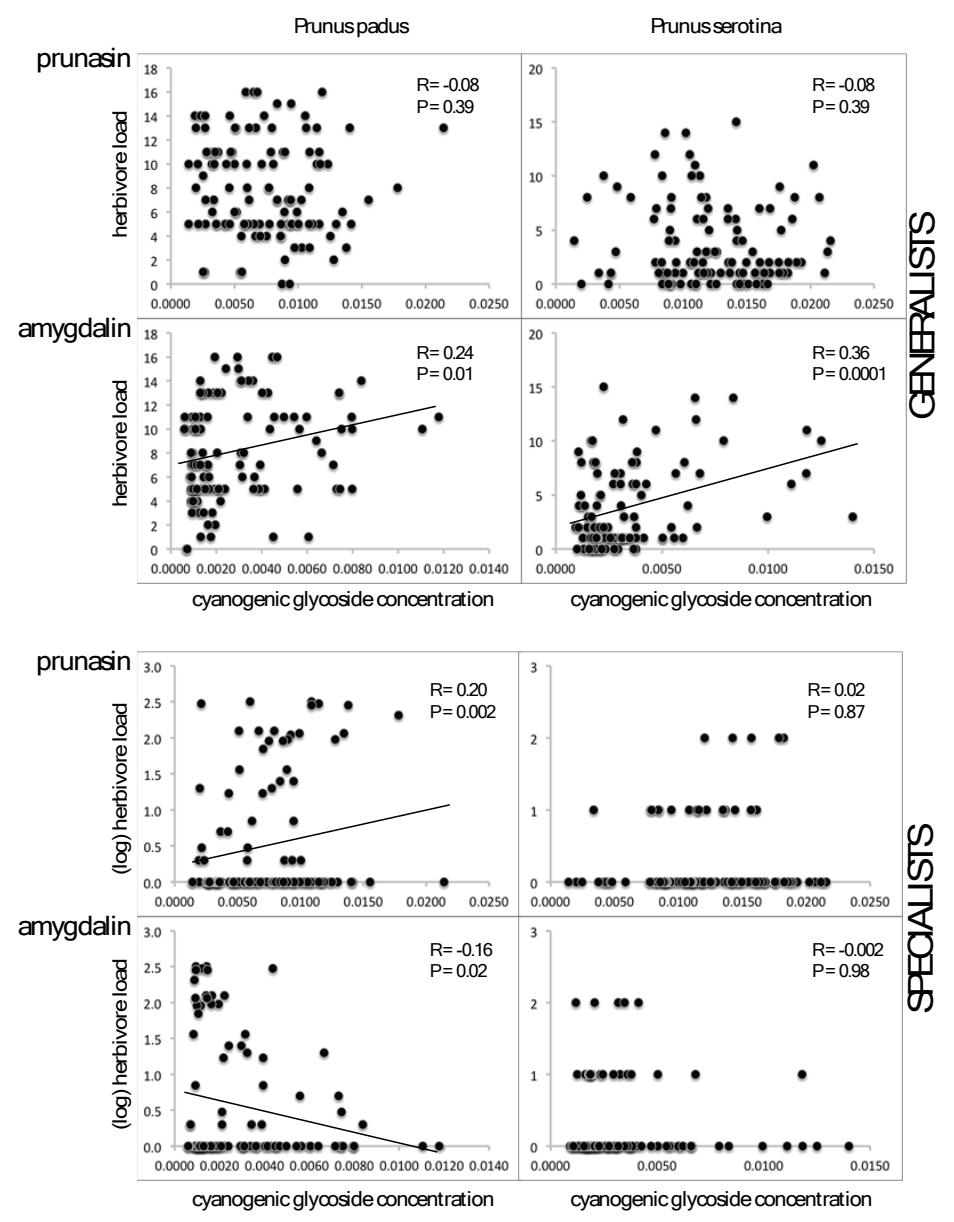

772

773 Figure 4. Cyanogenic glycosides and herbivory. Prunus padus is shown in the left column,

774 Prunus serotina in the right column. Data for generalist herbivores are shown in the top

775 four graphs (separately for prunasin and amygdalin), and for specialist herbivores in the

776 bottom four graphs (also separately for prunasin and amygdalin). Pearson correlation

777 coefficients (for the data for generalists) and Spearman's rho (for the data for specialists)

778 and corresponding $P$-values are given, and regression lines are shown for significant

779 relationships. Note that the $P$-value for amygdalin vs. specialists in $P$. padus does not

780 remain significant after Bonferroni correction. Herbivore loads (on the y-axis) are given as 
781 counts of individuals per tree, except in the case of specialists on P. padus, where the log

782 was taken. Cyanogenic glycoside amounts (on the x-axis) are given as NMR signal integrals.

783

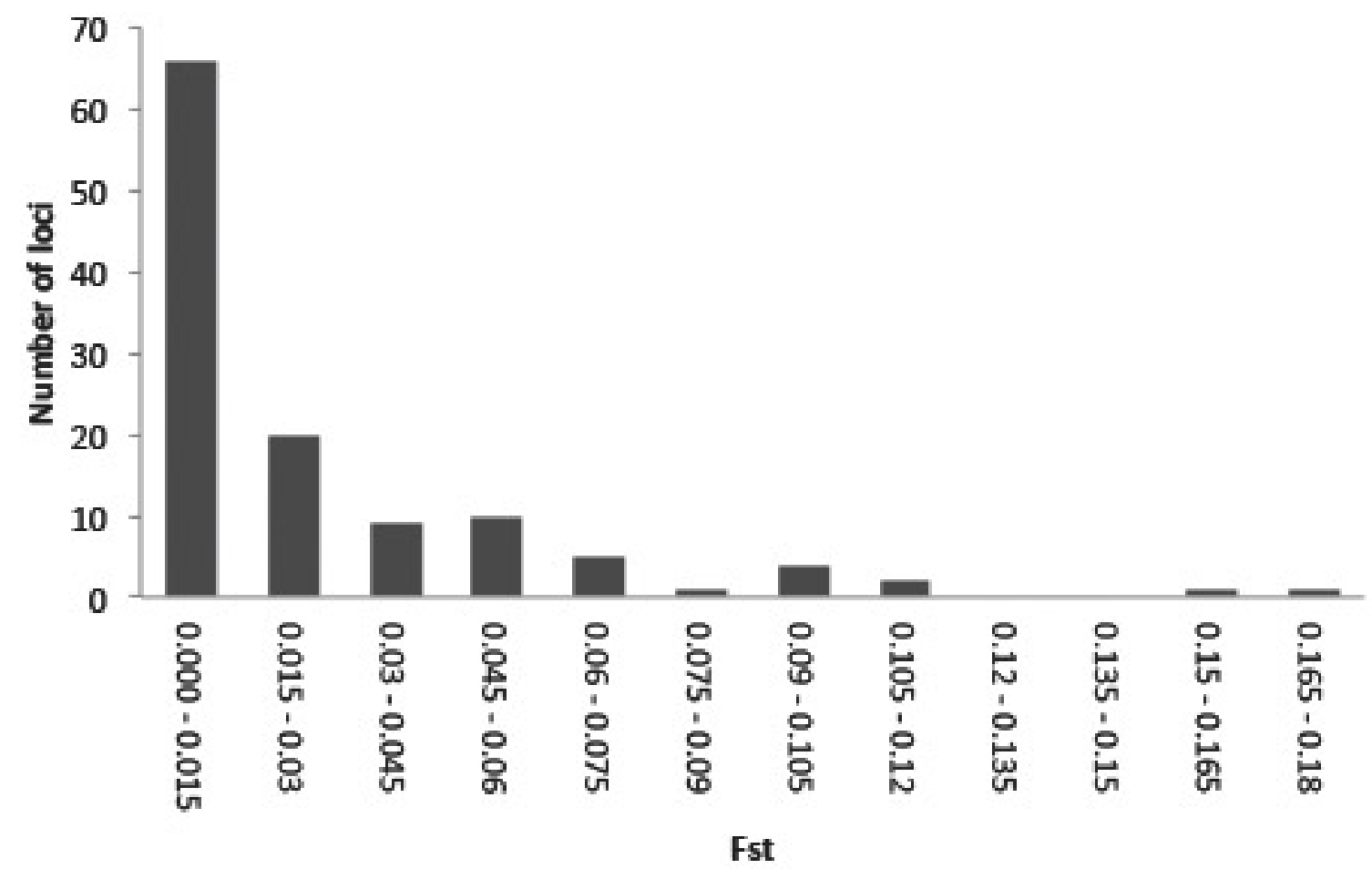

784

785 Figure 5. Frequency distribution of per-locus pairwise (Prunus-Sorbus) $\mathrm{F}_{\mathrm{ST}}$ values for 786 Gonioctena quinquepunctata. 


\section{Supporting Information (uploaded separately)}

788

789 Table S1. Full data on identities and numbers of herbivores collected on each individual

790 Prunus serotina and Prunus padus in National Park Zuid-Kennemerland.

791

792 Table S2. Information on insect herbivore damage in historical collection specimens from

793 the National Herbarium, Leiden, for Prunus serotina and Prunus padus.

794

795 Table S3. Full data on NMR analysis of Prunus leaves.

796

797 Table S4. SNP genotype data on Gonioctena quinquepunctata.

798

799 Table S5. Oligonucleotides used for the SNP-analysis of Gonioctena quinquepunctata.

800

801 Table S6. SNP Loci that showed indications of genetic differentiation between both host

802 plants in the leaf beetle Gonioctena quinquepunctata.

803

804 Table S7. ANOVA and GLM results for the Gonioctena quinquepunctata host preference 805 tests.

806

807 Table S8. Explanatory variables and response variables for the test of parasitzation of 808 caterpillars on P. serotina and P. padus.

809 
810 SI Text S1. Structure analysis and AMOVA on SNP data for Gonioctena quinquepunctata.

811

812 SI Text S2. Calculations of conversion of cyanogenic glycoside contents for dry and fresh

813 weight leaves. 